\title{
About agricultural manuals, gardens and coffee plantations: mosaics and landscape transformation in the Paraiba do Sul Valley, Brazil
}

Lucas Santa Cruz de Assis Brasil ${ }^{1}$, Rogério Ribeiro de Oliveira ${ }^{2}$

\begin{abstract}
Economic cycles have often become the landscape matrix, in a hybrid process of society-nature transformation, leaving distinct legacies in it. The coffee plantation showed great productivity in the Paraíba do Sul Valley to the detriment of forests, resulting in profound changes in geo-hydric cycles. Although the transformation by coffee has been significant on a spatial scale and in environmental changes, the Paraíba do Sul Valley landscape needs to be understood in a broader perspective. There were also other crops in the landscape inside or outside large estates. This work aims to recognize the spatial organization of these cultures and develop an understanding of the pattern of the coffee landscape, showing the performance of different social actors. The methodology consisted of a bibliographic review and analysis of historical agricultural manuals. Spatializing such past activities and social groups in the landscape shows us what was previously hidden, omitted by the traditional historical narrative This research showed that colonial knowledge developed a landscape compartmentalization, spatializing the crops according to pedological and topographic evidence.
\end{abstract}

Keywords: Coffee; Agricultural manuals; Atlantic Forest, Socioecological Legacies, Colonial Knowledge

\footnotetext{
${ }^{1} \mathrm{PhD}$ Student in Geography, Pontifical Catholic University of Rio de Janeiro. Researcher at Federal University of the State of Rio de Janeiro, Brazil. ORCID https://orcid.org/0000-0003-4325-9664. brasilucas@gmail.com

2 Doutor pela Universidade Federal do Rio de Janeiro, UFRJ, Brasil. Professor Associado da Pontifícia Universidade Católica do Rio de Janeiro, Departamento de Geografia e Meio Ambiente, Rio de Janeiro, Brasil. ORCID: https://orcid.org/0000-0002-2814-2620. rro@puc-rio.br
} 


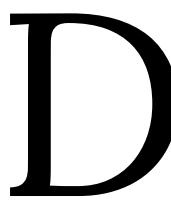
e Re Rustica was perhaps the first agricultural manual in the West. Written by Lucius Columella at the beginning of the Christian era, this agronomic treatise must have inspired the edition of several Brazilian manuals. In the early nineteenth century, several agricultural manuals appeared in the country, intending to bring some technical knowledge to agriculture. It was when coffee value increased as an international product, its production became extremely profitable. Soon, in the farms surrounding the Rio de Janeiro urban core, large productions hatched on immense lands and intensive slave labor, and later slave lords headed to new areas in search of maximizing their cultivation plots. One place in southeast Brazil, in a quick burst, flourished in wealth, being converted from forest to coffee farms, for this reason the landscape changed severely. The coffee, omnipresent in the landscape hid in its shadows small subsistence plots of slaves and masters. "The Empire is coffee, and coffee is the Valley". This saying was already circulating in the 19th century, showing the idea that the Paraiba do Sul Valley region in the provinces of Rio de Janeiro, São Paulo and Minas Gerais were organized around slavery, large rural properties, coffee production and exports. They were central elements in shaping the physical, political and cultural landscape of the Empire of Brazil.

The Paraíba do Sul Valley, located between two of the largest cities in Brazil today, Rio de Janeiro and São Paulo, quickly became the richest place in the Americas. The spatial transformation brought by the coffee activity in the region is well known: the vegetation cover removal, the implementation of monoculture crops based on enslaved labor, the gradual inland frontier expansion, the skyrocketing economic growth producing new trade routes, commerce, houses, villages, and public buildings, culminating later in the flourishing of towns and cities ${ }^{3,4,5,6,7}$.

\footnotetext{
${ }^{3}$ Marcelo E. Dantas, e Ana Luiza Coelho Netto. "Resultantes geo-hidroecológicas do ciclo cafeeiro (1780-1880) no médio vale do rio Paraíba do Sul: uma análise quali-quantitativa." Anuário do Instituto de Geociências, (1996): 61-78.

${ }^{4}$ Adi E. Lazos-Ruiz, Ana Luíza Coelho Netto, Marcelo Dantas, e Rogério Ribeiro Oliveira. "Cenários do passado no Vale do Rio Paraíba do Sul." In Geografia Histórica do Café no Vale do Rio Paraíba do Sul, edited by Rogério R. Oliveira e Adi E.Lazos-Ruiz, (Rio de Janeiro: Editora PUC-Rio, 2018): $61-82$

${ }^{5}$ Rafael B. Marquese. "Diáspora africana, escravidão e a paisagem da cafeicultura no Vale do Paraíba oitocentista." Almanack braziliense 7 (2008): 138-152.

6 José Augusto Pádua. Um sopro de destruição: pensamento político e crítica ambiental no Brasil escravista, 1786-1888. (Rio de Janeiro: Zahar, 2002): $318 p$.

${ }^{7}$ Maria Verónica Secreto. "Dominando la floresta tropical: desbravamentos para el café paulista (Brasil siglo XIX). Theomai, 1 (2000)
} 
The Paraíba do Sul Valley is a formation that crosses the border of the current states of São Paulo, Minas Gerais and Rio de Janeiro (Figure 1). The river strength produced numerous river terraces in its course, and its rushing waters and broad banks made many navigable stretches. By the bed of this watercourse, indigenous groups traveled, composing old ways, the 'peabirus', being the main route to the Puris, an indigenous group that lived by the shore, to seek refugee while the colonists advanced through the $\operatorname{cost}^{8}$. The indigenous peoples of the territory we now know as Brazil, contrary to the widely accepted assumption they did not alter the vegetation cover during the pre-European period, did change the Brazilian landscape ${ }^{9,10,11}$ and their uses of nature are the first mark we have to bear in mind when thinking about the Paraíba do Sul Valley Historical Geography.

Figure 1. Paraíba do Sul River medium course covering the states of Rio de Janeiro, Espírito Santo and Minas Gerais.

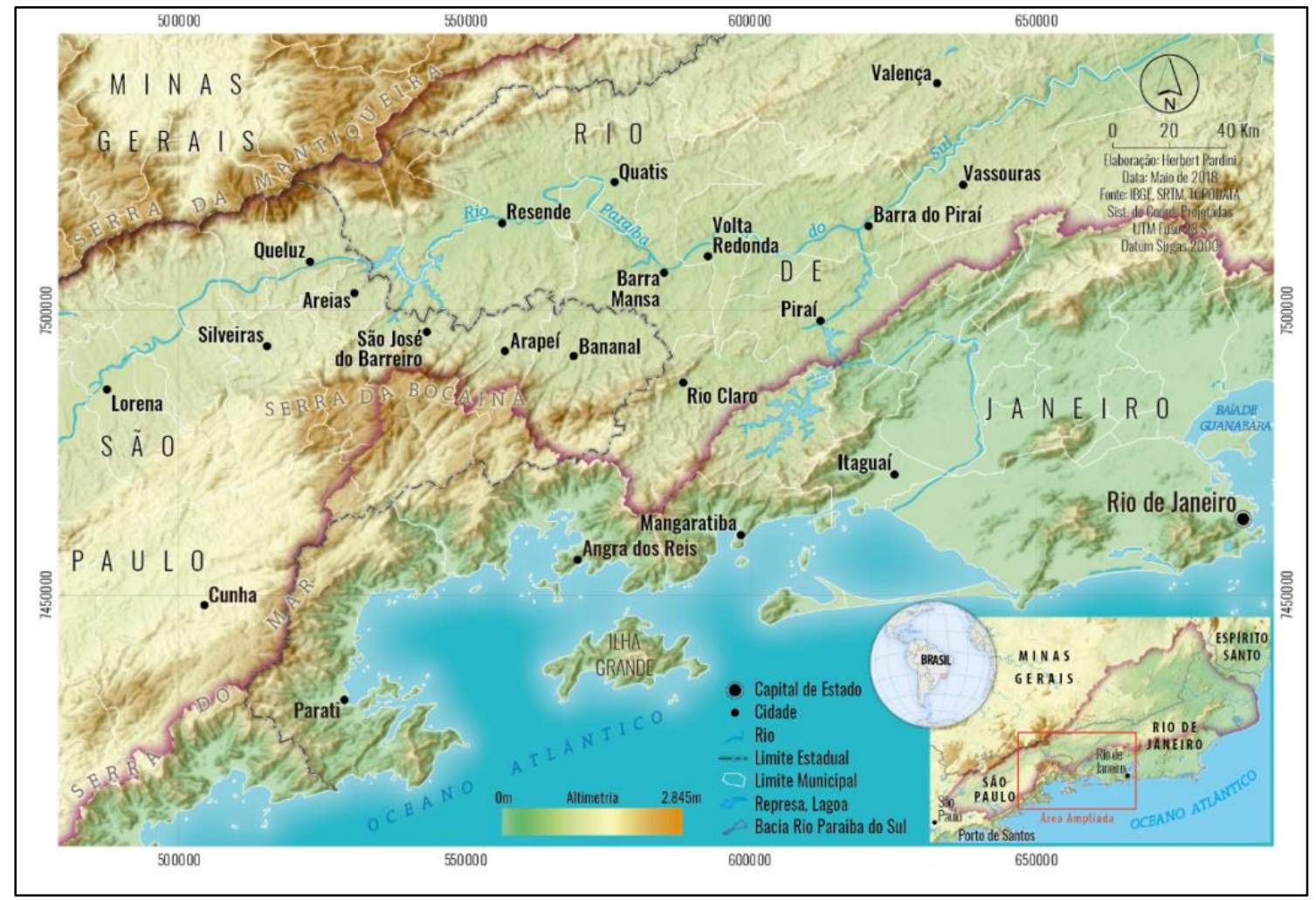

Elaborate by Hebert Pardini, 2018.

\footnotetext{
8 Jeronimo de P. Silva, "Índios do Vale do Paraíba". In História e Geografia do Vale do Paraíba, edited by Neusa Fernandes and Olivio G. P. Coelho, (Rio de Janeiro: Instituto Histórico e Geográfico de Vassouras, 2013): 81-86.

${ }^{9}$ Antonio Carlos Diegues. O mito moderno da natureza intocada. (São Paulo: Hucitec, 1996): 169p

${ }^{10}$ Rogério R. de Oliveira. "Mata Atlântica, paleoterritórios e história ambiental". Ambiente \& Sociedade 10, 2, (2007): 11-23.

${ }^{11}$ Rogério R. de Oliveira; Carlos Engemann. "História da paisagem e paisagens sem história: a presença humana na Floresta Atlântica do Sudeste Brasileiro." Esboços-Revista do Programa de Pós-Graduação em História da UFSC, 18, 25, (2011): 9-31
} 
Once the Serra do Mar's steep slopes have been crossed, colonists have reached this valley of warmer temperatures, milder than those of the coast and endowed with fertile ground - attested by the abundance of their forests. Thus, once climbed the Serra do Mar, they used the Paraíba do Sul Valley as a dispersion axis to the west, towards the São Paulo state plateau or towards the east, reaching Espírito Santo state or towards the north reaching the Minas Gerais state (Figure 2).

Figure 2. A chronological dispersal map showing the three main directions that the coffee production took in the nineteenth and early twentieth centuries.

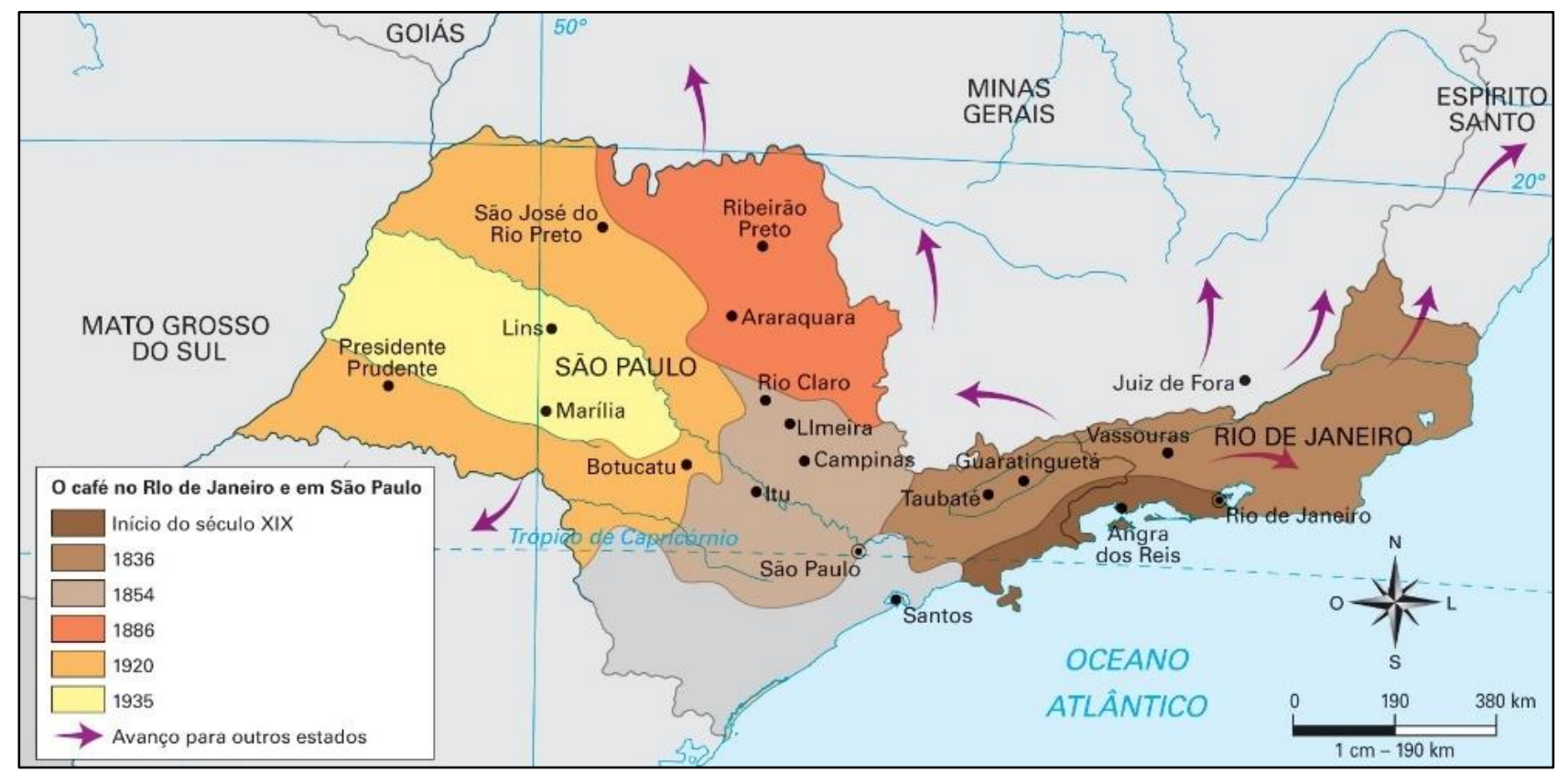

Extracted from: http://historiaantares.net/estudos/paranasantos.html

This agricultural frontier expansion spilled the coffee plantations in areas that were still endowed with a large forest percentage in landscape composition ${ }^{12}$.With the arrival of the European and the different uses that Portuguese submitted the new lands, a whole new game of nature alteration/construction began. The indigenous uses of nature and their consequent marks were no longer alone in the landscape. The colonizer sometimes appropriated them, sometimes replaced them and sometimes deleted them ${ }^{13}$.

\footnotetext{
12 Secreto, "Dominando la floresta tropical ..."

${ }^{13}$ Rogério R. de Oliveira; Verena Winiwarter. "Toiling in Paradise: knowledge acquisition in the context of colonial agriculture in Brazil's Atlantic

Forest Context of Colonial Agriculture". Environment and History, 16, (2010): 483-508
} 
Studies on the Paraíba do Sul River Valley ${ }^{14,15,16}$, however, focused on the monoculture farms, in areas managed by big slaveholders, assuming these historical agents as the only landscape modifiers (and participants). The happenings following the coffee activity decline are little debated, especially referring to landscape production and the legacies contained therein, still present in the region.

However, it is necessary to understand the past landscape and the legacies to think about the spatial transformations that added up through time, with the historical geography contributing to fill this (still) large knowledge gap. Thus, the challenge is, according to Paulo César da Costa Gomes' proposal, to compose true "geographical pictures", indicating the location and diversity of the spatial phenomena, also allowing one to see the relations between the phenomena by its simple disposition on a cartographic plan. In this way, one can "start from the location to think about relationships, judge proximity or distances"17 an indispensable exercise in geographical thinking, articulating those varied special phenomena together, and being able to reconstruct their interactions on space.

\section{WHAT IS MISSING IN COLONIAL COFFEE BRAZILIAN HISTORIOGRAPHY?}

A commonplace in Brazilian historiography is to reduce colonial Brazil to its biggest economic ventures - the pau-brasil (Paubrasilia echinata) extraction in the sixteenth century, the sugarcane production in the seventeenth and eighteenth, the gold mining rush in the seventeenth and the coffee enterprise in the nineteenth. Studies concentration on these themes contributes to the idea of a colonial space appropriated only by big producers and by the landowner monoculture slave logic. Our historiography would be marked by a "plantationist" point of view, exacerbating large agricultural products in the colonial rural space composition ${ }^{18}$. The whole landscape would then be used directly to obtain a single "king product", as if in

\footnotetext{
${ }^{14}$ Affonso d'Escragnolle Taunay. Pequena História do Café no Brasil 1727-1937. (Rio de Janeiro: Departamento Nacional do Café, 1945): 558p

${ }^{15}$ Stanley J Stein. Vassouras um município brasileiro do café, 1850-1900. (Rio de Janeiro: Nova Fronteira, 1990): 361p

16 Dean, "A ferro e fogo..."

17 Paulo César da Costa Gomes. Quadros Geográficos: uma forma de ver, uma forma de pensar. (Rio de Janeiro: Bertrand, 2017): 160p

18 Maria Yêda Linhares. "Pecuária, alimentos e sistemas agrários no Brasil (séculos XVII e XVIII)". Arquivos do Centro Cultural Calouste

Gulbenkian, Le Portugal et l'Europe Atlantique, le Brésil et l'Amérique Latine, 34, (1996): p.5
} 
Brazilian landscape there were only sugar cane plantations or, later, only coffee crops through the hills.

In this way, other existing agricultural productions, aimed at supplying both large farms and urban sites, are concealed. To avoid an overly simplistic view of the past, rethink that landscape is needed, assuming it with greater complexity than usual in traditional historiography. Agricultural production was vast: the cassava (Manihot esculenta) had a prevalence in the market, an indigenous diet permanence; corn, coming from the contact areas with the pre-Andean mountains ${ }^{19}$; and sweet potato, whose origin goes back until central Peru ${ }^{20}$.In summary, there were more than just monocultures composing the landscape of colonial Brazil, there were other cultures associated with rural existence, other practices, other cultivation techniques, and other knowledge.

In colonial Brazil, according to Maria Yedda Linhares, the rural economy was configured in three "landscapes": large-scale farming, supply-based farming and extensive livestock. She argues that those landscapes were never dissociated from each other: on the contrary, when not simultaneous, they occurred successive, in an agrarian macro-model.

Ruy Moreira's reflections meet Linhares' statements. Although the entire productive system was oriented towards a major export-oriented genre, there was also an internal system that determined spatial interactions with other "macroforms" as Moreira calls it. In Moreira's model, he claims four different spaces: agricultural space, pastoral space, plant-extractive space, and the urban space ${ }^{21}$. These spaces had their specificities - which allows us to differentiate them - being the network built between them a demonstration of spatial interactions in the nineteenth century Paraíba do Sul Valley. Other cultures present in the nineteenth-century coffee landscape and associated land uses have been identified through the research

\footnotetext{
${ }^{19}$ Maria Yêda Linhares. "Pecuária, alimentos e sistemas agrários ..." p.13

20 Donald Ugent e Linda W. Peterson, "Archeological Remains of Potato and Sweet Potato in Peru," CIP Circular, 16 (1988): 1-10.

${ }^{21}$ Ruy Moreira. A formação espacial brasileira: contribuição crítica aos fundamentos espaciais da geografia do Brasil (Consequencia: Rio de Janeiro, 2014): 320p
} 
process: the "peasant gap" made by enslaved blacks ${ }^{22}$; small farmers, independent free men or associated (as settlers) with the great landlords; and finally the drovers ${ }^{23}$, merchants with a vast terrestrial trading network.

It is relevant to state that in this work we intend to shed light not only on the vegetation cover transformations of the Paraiba do Sul Valley and its subsequent conversion into pastures at the end of the coffee economy but mainly in which places of the landscape this occurred preferentially. The questions we try to answer are: where, preferably, were the crops established? Where did they sow coffee? Where did they plant cassava? Where pasture areas were commonly established? And what about the black enslaved agency? Or smallholder's agency in the landscape? Where were them in the landscape? Thus, this work aims to recognize the spatial organization of these groups and develop an understanding of a likely occupation pattern in the Vale do Paraiba do Sul landscape, which may help in the understanding of its transformations during and after the coffee cycle by identifying the marks produced in those times and that come to nowadays through socioecological legacies. In this intense landscape transformation process, the agricultural manuals played an important role, as we are about to see below.

The methodological procedures consisted of a bibliographic survey about the region, about the rise and decline of coffee, the different social groups present in the landscape and their economic activities and forms of interaction with the non-human world in colonial and imperial Brazil. The literature produced in the field of agrarian history has been essential in bringing to light the existence and action of human groups other than 'omnipotent masters' and 'subjugated enslaved Africans', a dichotomy that still needs to be fought. The documentary analysis to understand the current plant techniques was based on Agricultural Manual from the eighteenth and nineteenth century.

\footnotetext{
22 Ciro Flamarion S. Cardoso. "A brecha camponesa no sistema escravista" [1979]. In.: Camponeses brasileiros: leituras e interpretações clássicas, v. 1. Edited by Clifford Andrew Welch et al. (São Paulo: Editora UNESP, 2009).

23 The "drovers" here called by this name due to the lack of a better translation, traders who relied on mules to carry their goods through the steeps lands of the Serra do Mar and Serra da Mantiqueira in southeast Brazil. Their importance shall be highlighted later in this article.
} 
The manuals studied until this moment were the "Brazilian Farmer's Manual"24, written by Carlos Augusto Taunay, first printed in 1839; "Memory of the founding and coastline of a farm in the province of Rio de Janeiro: By Baron Paty do Alferes, and annotated by Dr. Luiz Peixoto de Lacerda Werneck"25, whose first edition dates from 1847; and finally, from 1863 the "Food Staples Farmer's Handbook or Method of the Mixed Culture of these Genres in Tired Lands" by Father Antonio Caetano da Fonseca $^{26}$.

\section{AGRICULTURAL MANUALS - SPATIALIZED COLONIAL KNOWLEDGE ON COFFEE FARMS}

We understand that the so-called colonial knowledge about coffee farms was something very hybrid (both theoretical and practical), but based mainly on European knowledge. Indigenous knowledge about agriculture was largely ignored. Agricultural manuals are interesting documents because they contain the best practices and techniques believed at that time for the rural properties proper functioning. They allow us to access how colonial knowledge understood, interpreted, managed and interacted with the tropical world. They offer a glance on how Europeans saw the New World's nature, and how they thought this new nature should be handled to achieve the highest profits possible. Influential handouts among the agrarian elite, those manuals were commonly the only secular books in the masters' houses and were widely adopted by big producers ${ }^{27}$. They provided evidences of which terrains were best suited to which crops, what can explain the spatial organization and which forces, knowledge and social actors were involved in the landscape sectioning.

The first volumes were imported from the Antilles agronomists, importing also the methods and techniques observed there. Throughout the organization and systematization process of an agronomic knowledge focused on Brazilian characteristics, one fact is relevant: the first Brazilian agricultural manual appeared

\footnotetext{
${ }^{24}$ Carlos Augusto Taunay. Manual do agricultor brasileiro. (São Paulo: Editora Companhia das Letras, 2001): 327p

${ }^{25}$ Luiz Peixoto de Lacerda Werneck. Memoria sobre a fundação e costeio de uma fazenda na provincia do Rio de Janeiro: Pelo Barão do Paty do Alferes, e annotada pelo Dr. Luiz Peixoto de Lacerda Werneck (1863)

${ }^{26}$ Padre Antonio Caetano da Fonseca. Manual do Agricultor do Generos Alimenticios ou Methodo da cultura mixta destes gêneros nas terras cansadas (Rio de Janeiro: Editores Eduardo \& Henrique Laemmert, 1863)

27 Rogério Oliveira and Verena Winiwarter. "Toiling in Paradise..."
} 
only three centuries after the sugarcane implementation in the country. It was not until the 1830's that an effectively Brazilian production of agricultural manuals and guidelines, geared to the demands and conditions of colonial Brazil, flourished ${ }^{28}$. All the knowledge available to farmers came from imported oral tradition, experience or European manuals. There is not one single positive reference in these writings to the agricultural techniques used by indigenous. The dominant view of the Europeans regarding the Atlantic Forest soils was that they were rich and very fertile (which we now know it is not entirely true), but the indigenous' agricultural knowledge was primitive and rudimentary ${ }^{29}$, and did not deserve much attention.

A good start to think about economic activities distribution in the landscape is to consider the topography of the place and its relationship with the soil types presented. Much more than just physical support for the different human groups establishment, relief should also be interpreted as a natural resource ${ }^{30}$, as the variation of forms that different terrains present can facilitate or hinder certain economic activities. In general, European colonizers showed a preference for flatter or less inclined places, due to the greater ease of farming or constituting urban sites. ${ }^{31}$

In "Brazilian Farmer's Manual" Taunay ${ }^{32}$ gave us relevant documentation in that sense. The author dealt with the main tropical crops, ways in which they should be worked, farmer main challenges, the machinery available, favorable technologies, etc. Taunay made an impressive effort to classify the soils from the topography he had contact with. He simplified pedological variety in three main soil types: massapê, clay and sand.

Decision-making on crop distribution was determined by the flagship of the coffee landscape: the Arabian grain had been identified as a mesic crop, meaning that its maximum development was not on dry land, neither on wetlands, but in those with balanced drainage ${ }^{33}$. Thus, the highest (far from the groundwater) lands and the lower

\footnotetext{
${ }^{28}$ Rafael Marquese. "Diáspora africana, escravidão e a paisagem da cafeicultura ..."

${ }^{29}$ Rogério Oliveira and Verena Winiwarter. "Toiling in Paradise..."

30 Jurandyr Luciano Sanches Ross. Ecogeografia do Brasil: subsídios para planejamento ambiental. (São Paulo: Oficina de Textos, 2006): 208p.

31 Jurandyr Ross. Ecogeografia do Brasil

32 Carlos Taunay. Manual do agricultor brasileiro.

33 Rafael Marquese. "Diáspora africana, escravidão e a paisagem da cafeicultura ..."
} 
(periodically flooded) ones such as riverbanks were excluded as a possibility to accommodate the Coffee arabica individuals, which fully developed between these two relief parts: the middle slopes (Figure 3). It is interesting to note that there was a partitioning of the land according to the best use of each cultivar, an edaphic association based on the colonizers' knowledge. Analyzing his writings, it is evident how the coffee ended up having a specific location on the land, always producing better in the hillside areas, where, according to the author, figured the clay lands.

Figure 3. The coffee harvest. Paraíba do Sul River Valle.

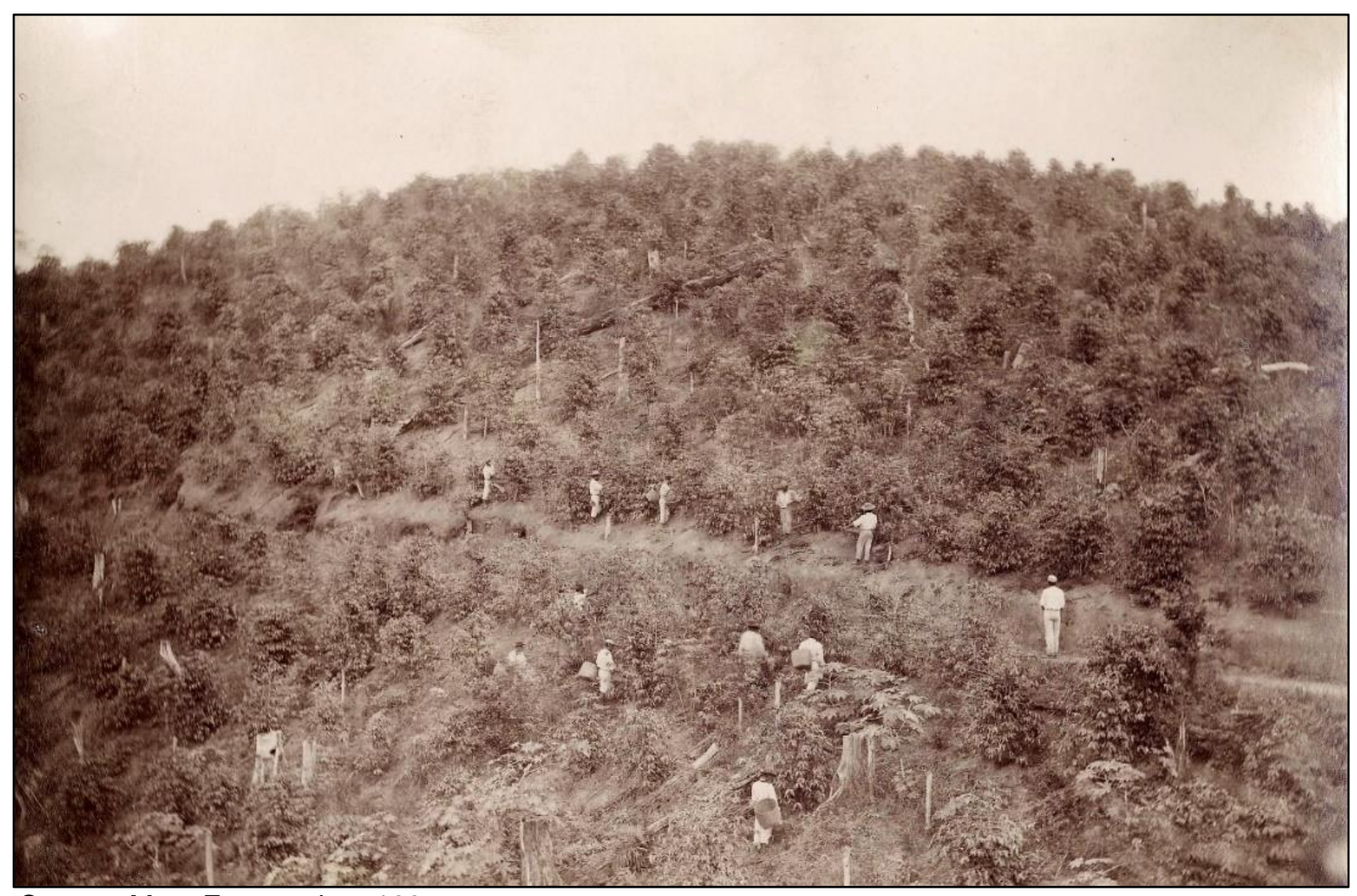

Source: Marc Ferrez, circa 1885

In 1958, Ab'Saber and Bernardes ${ }^{34}$ pointed out that in the Paraíba do Sul Valley higher-altitude segments, with more and better annually distributed rainfall, in the neighboring Serra do Mar range, there was a coffee expansion limitation, because it did not offer ideal climatic conditions for the grain cultivation. Constantino Fraga also reports that the most suitable land for coffee farming was between 300 and 600 culturas, ecologias e as transformações históricas da Mata Atlântica edited by Diego Cabral and Ana Bustamante. (Curitiba: Prismas, 2016): 286304

${ }^{34}$ Azziz Nacib Ab'Saber and Nilo Bernardes. "O Vale do Paraíba, Serra da Mantiqueira e arredores de São Paulo". In Congresso Internacional De Geografia. (Rio de Janeiro: CNG, 1958): 303p. 
meters in altitude, and it was not profitable to invest elsewhere ${ }^{35}$, laying a hint on why so many coffee farms concentrated in the middle section of the topography.

Far from lowlands or plains, soggy or poorly drained soils, grain crops always seemed to be more productive on "mud" land, with clay abundance. It should be noted that, as Taunay's described, those lands weren't very rich in humus in its composition, which is why the author claimed that those are lands that lose fertility quickly, as opposed to massapê. As the author puts it, the massapê lands are alluvial soils, that is, they receive soil particles from upstream portions that carry nutrients, minerals, and organic matter, therefore making it suitable for other agricultural activities. In contrast, the clay soils "deteriorate rapidly, especially in the hills', leading us to the conclusion that these soils were located on the slopes, erosion-prone areas, providing sediment and organic matter to the lower ground. Coffee should be grown in the so called "hill's seas", with the fertile soil (albeit in a short term) generated by the slash and burn of forest vegetation that existed there.

Thus, one can infer that for each crop - greenery, cassava, corn, beans, sugar cane, orchards and pasture - corresponded a better partitioning in the relief, with appropriate pedological, hydrological, and micro and mesoclimathic characteristics. These manuals, as written by Taunay, recommended floodplains full of humus and alluvial material to sugarcane, cacao, and vegetables ${ }^{36}$, as the floodplains were known for their fertility and water retention capacity, ${ }^{37}$ making the banks of rivers an optimum site of occupation and agricultural development in the valley.

The pastures, which were intended to support animal husbandry on the farms, were not assigned any particular portion of the land. In fact, in Priest Antonio Caetano da Fonseca's agricultural manual, he recommends that they should be formed in the property's most deteriorated areas:

Since my sole intention is to teach the farmer the means of making fertile, the land sterile by exhaustion, I would advise him to choose the most exhausted places on his farm to make a pasture capable of supporting as many cattle as needed to give

\footnotetext{
35 Constantino Fraga. Resenha histórica do café no Brasil. Agricultura em São Paulo 10, 1, (1963): 1-21.

${ }^{36}$ Carlos Taunay. Manual do agricultor brasileiro.

${ }^{37}$ Rogério Oliveira and Verena Winiwarter. "Toiling in Paradise..."
} 
enough manure to fertilize the land of his plantation, reserving the places that still have some virgin vegetation, and using capoeira ${ }^{38}$ for firewood and building woods. ${ }^{39}$

The pastures were relegated to spaces that didn't meet the coffee requirements or the food crops demands. Because they were less demanding than the aforementioned crops, they could be established in less noble and even depleted areas, who suffered from an intensive monoculture regime in previous years. Although Fonseca suggests that the manure can be used to bring the soil fertility back, the general belief was that coffee could only strive in forest soil, legitimizing the expansion of the agricultural frontier despite the original vegetation cover ${ }^{40}$.

There is still an additional problem in raising cattle near plantations. How to keep cattle away from crops? Barbed wire dates from the late 19th century and was barely accessible to Brazilian farmers. This difficulty was partially overcome by the use of bamboo fences or by the excavation of ditches that prevented the movement of cattle. ${ }^{41}$ Traces of these fences are still found in the landscape of the region (Figure 4).

Therefore, some production loci determined by colonial knowledge in the landscape of the region were identified: the not so high, more drained slopes, the socalled "half-oranges" - the clay lands - were reserved for planting coffee at the Paraíba do Sul Valley, where the coffee plant produced better. Fluvial plains, fertile alluvial lands, but with higher water concentration, - the massapê - lands were suitable for sugarcane cultivation, and most of the foodstuffs.

\section{OTHER AGENCIES, OTHER LANDSCAPES}

We will now discuss other agricultural activities associated with different social actors. As these activities required unique landscape management, they

\footnotetext{
38 "Capoeira" is the name given in rural areas to secondary vegetation that come after a slash event or crop abandonment.

39 "Sendo o meu único intento ensinar ao fazendeiro os meios de tornar férteis os terrenos estéreis por cançados, aproveitando-os inteligentemente para o que servirem, aconselharei que escolha os lugares mais cançados da sua fazenda para fazer um pasto capaz de sustentar tanto gado, quanto seja preciso para dar extrume sufficiente para adubar o terreno da sua plantação, reservando os lugares que ainda tiverem algum matlo virgem, e capoeira para lenha, e madeiras de construcção." Padre Fonseca. Manual do Agricultor do Generos Alimenticios, p.13-14.

40J.A. Pádua. Um sopro de destruição

${ }^{41}$ Rogério R. de Oliveira. Fruto da terra e do trabalho humano: paleoterritórios e diversidade da Mata Atlântica no Sudeste brasileiro. Revista de História Regional, 20, (2015): 277-299.
} 
About agricultural manuals, gardens and coffee plantations:

mosaics and landscape transformation in the Paraiba do Sul Valley, Brazil

Lucas Santa Cruz de Assis Brasil

Figure 4. Ways to contain or dominate cattle in the XIX century.
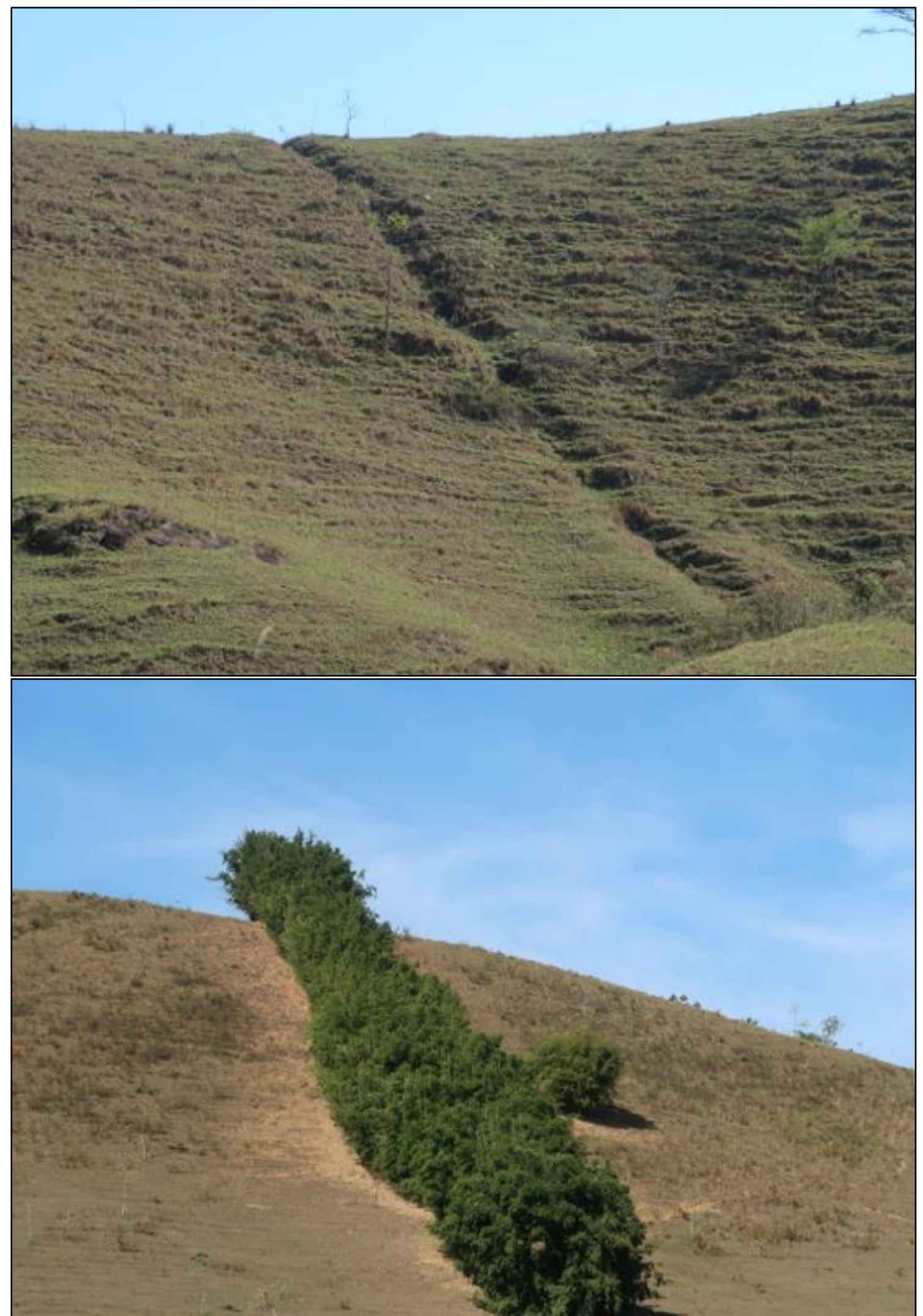

On top, a ditch that prevented the movement of cattle with an original section of $2.0 \times 2.0 \mathrm{~m}$. On botton, bamboos lined up making a hedge in Bananal municipality, Paraíba do Sul Valley. Source: Rogério Oliveira, 2019. 
produced distinct socio-ecological results from those of the colonial "plantationism". Not only did different species adapt better to different terrain compartments, but they also required specific care, knowledge, and techniques. Each crop is dependent on a specie management handling and, consequently, to a landscape management way. Each cultivation is associated with a proper culture on how to deal with such life forms, built to present the desired results aimed by the producer. Each landscape was composed of several activities, and different social actors performed them. As each enterprise demanded different knowledge, techniques, resources, and deadlines to be met, it is possible to affirm that there was both spatial and cultural specialization in these productions through the landscape. Using specific technologies, specific marks have also been left on the landscape, some still discernible until these days, whether they are imprints on the soil, today's forest structure and composition, exotic grasslands distribution or some cultural species abundance in the landscape.

Although these places managed by other agents were often within the landowner domain, such landscapes of autonomy built on species, cultivation techniques, ritual and religious practices guided by the customs, values, and preferences of different social actors. To recognize their agency in the landscape is also to acknowledge their participation in the historical process since they still struggle with invisibility not only in Brazilian historiography but also in Brazilian society as a whole.

\section{SMALLHOLDERS}

The smallholders were a social group composed of free man, who did not have much power or lands. Their production attended the internal market needs, mainly fresh vegetables and fruits. The expansion frontier was a space in which small farmers used to settle, getting into Brazil's backlands, using lands not desired by coffee lords due to the lack of resources in it or areas not yet occupied by the plantation. Those authors situate the precarious and transitory way in which this food production took place, since the best lands were integrated to the coffee production, as soon as the 
agricultural border expanded, making the small farmers land only "provisional plots" 42.

The small farmers were pushed to the higher and more distant lands: uninviting for coffee cultivation, those mountainous segments would have remained largely forested and managed by small farmers who used it according to traditional "roças" (slash and burn system) and for coal production and wood extraction ${ }^{43,44}$. In general, such sites presented a process quite distinct from the landscape transformation by coffee that the most arable lowlands experienced. The Valley also had parallel ridges at its ends: the peaks of the Serra do Mar, to the south, and the Serra da Mantiqueira, to the north, limited its ramps. The summits of these elevations, with mild temperatures and stony, well-drained soils did not provide the necessary conditions for coffee plantation. The low temperatures in the winter could cause frost, which is a death sentence not only to that year's yield, but to the coffee plant as well. The difficult access to water in those heights also limited the grain development. The topography of these sections combined with the increased distance to markets and main roads also offered a limitation to these areas. No wonder these places were the stronghold of small besiegers, free men who did not reside in the coffee farms, who, shunned from the most fertile land, sought their sustenance in lands not desired by the "green gold" or sugarcane production.

Despite the importance of such local food security generating activities, they have always been spatially neglected, with the best lands, as noted above, intended for export trade. The transience of these human settlements, despite playing an important role in the colonial Brazil opening frontier, limited their landscape marks intensity, being the most evident in present-day old banana trees occurrence in areas currently forested ${ }^{45}$, indicating past use by small besiegers, in places where the woods have returned to their former posts. In addition, other exotic species can be found at the mountains of Serra da Bocaina, indicating past human presence. Among them

\footnotetext{
42 Maria Yedda Linhares; Francisco Carlos Teixeira Silva. "A questão da agricultura de subsistência" [1981]. In: Camponeses brasileiros: leituras e interpretações clássicas. Edited by C. Walch (São Paulo: Editora UNESP, 2009), p. 117-133, p.119.

${ }^{43}$ Rogério Ribeiro Jorge. "Quem decide por nós é o IBAMA: As contradições na convivência com as populações locais no Parque Nacional da

Serra da Bocaina." In: Olhares geográficos: meio ambiente e saúde. Edited By Helena Ribeiro (São Paulo: Editora Senac, 2005): p. 31-64

${ }^{44}$ Ab'Saber and Nilo Bernardes. "O Vale do Paraíba...".

45 Ruy Moreira. A formação espacial brasileira
} 
there are cocoa (Theobroma cacao) and a kind of lemon (limão-galego, Citrus aurantifolia). Most likely, there were simple houses used by the drovers who moved through the mountains.

\section{DROVERS}

The freeman who specialized in cargo transport with mules was given the name of "tropeiro" (drover): a man accustomed to traveling carrying many goods and few personal belongings. The trade routes that would cross the Serra do Mar and Mantiqueira escarpments were exclusively composed of mule troops (Figure 5). During the coffee production heyday, the drovers were responsible for carrying bags with coffee beans to the ports to load the ships who sailed to the metropolis. When they returned to the Paraiba do Sul Valley, they used to bring merchandise like salt, cachaça and imported goods such as cutlery and tools. Sérgio Buarque de Holanda points to the first quarter of the eighteenth century as the moment when the mule troops began to be massively introduced into São Paulo state, coming mainly from the south, heading for the lucrative mines inside the colony, and fostering new creations of mules in the interior along this process ${ }^{46}$. The mules were a valuable resource since they were the only animal capable of carrying weight through the rugged steeps of Serra do Mar, once horses and ox carts simply couldn't do the job. The ox carts were used inside and outside the farms but couldn't go very far due to the relief: they weren't suited to the regional sierras sloping. It was these two animals, the mule, and the ox, that contributed most to the cargo transportation in the seventeenth, eighteenth and nineteenth centuries, being supplanted only when the railways were implemented in Brazil ${ }^{47}$.

The drover could be considered "the direct successor of the sertanista ${ }^{48}$ and the precursor, in many points, of the great farmer"49. The road roughness required

\footnotetext{
${ }^{46}$ Sérgio Buarque de Holanda. Caminhos e Fronteiras. (São Paulo: Companhia das Letras, 2017): 354p, p.159

${ }^{47}$ Alfredo Ellis Junior. "O ciclo do muar". Revista de Historia, 1, 1, (1950): 73-81

48 The "sertanistas" whom Holanda refers to are also called "bandeirantes", men who entered the Brazilian inland seeking precious stones, indigenous populations to enslave or slaves who fled from their masters. Through those activities, the bandeirantes were responsible for much of
} 
men who had rusticity as a way of life, as did the "bandeirantes" who had entered the territory years before. Its mercantile forays into the territory helped to sediment old routes as well as create new ones, expanding the Brazilian territory occupation. Numerous overnight stops - the so called "ranchos" (Figure 6) - and trade points that were established along the mercantile routes gradually grew into small villages and later onto cities.

Figure 5. Drovers moving (“Tropa em movimento"). Vale do Paraíba do Sul.

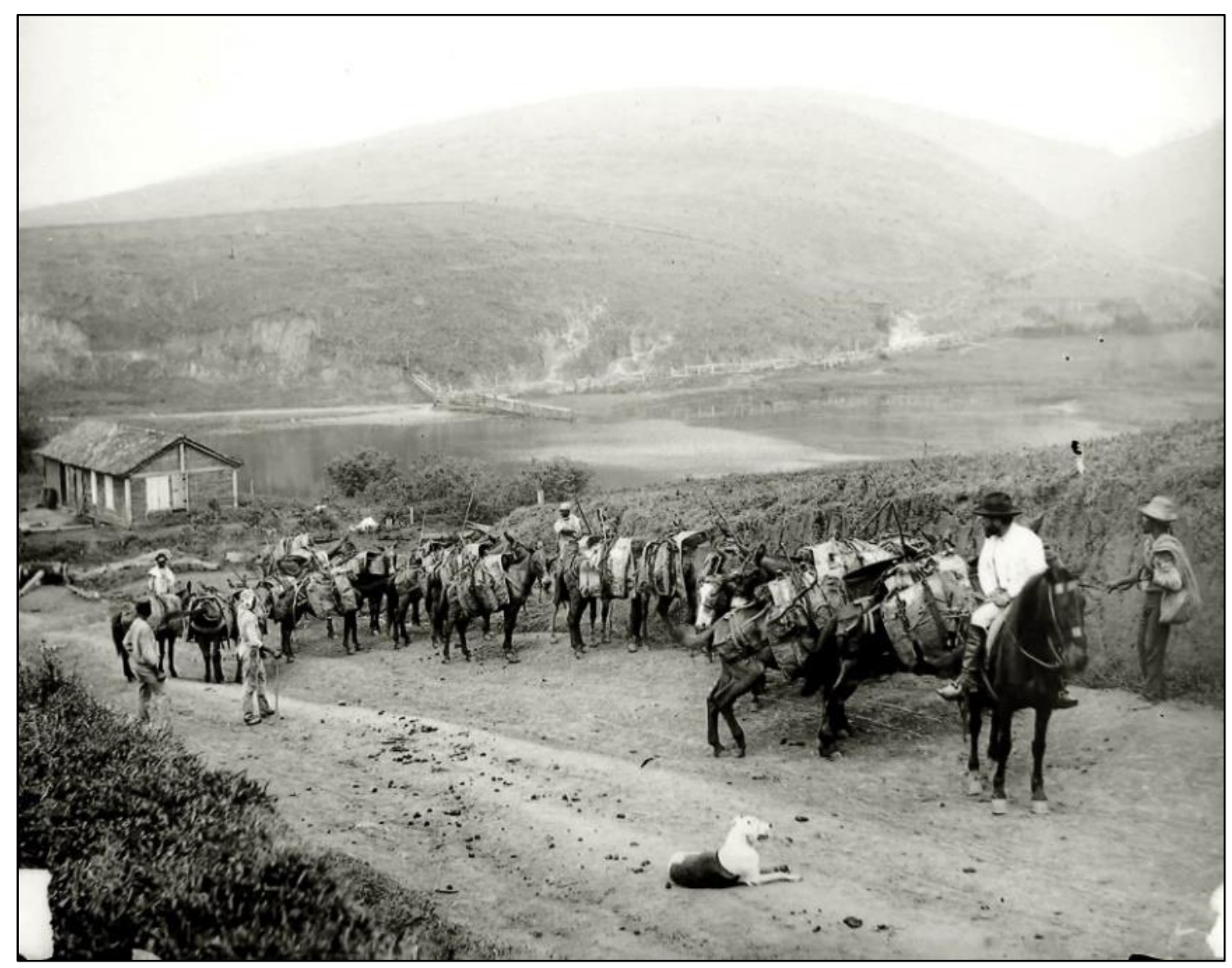

Source: Marc Ferrez, circa 1885

This circulation of people, goods, and currencies would soon leverage the development of these areas, boosting trade as a whole, generating farm growth and constituting one of the driving forces of landscape transformation in the Paraiba do Sul Valley, enabling new connections and establishing a solid commercial network. ${ }^{50}$

${ }^{50}$ Rogério R. de Oliveira. "Fruto da terra e do trabalho humano..." 
Also, daily life in dealing with animals brought them closer to a herding culture, and many became cattle ranchers later when the coffee declined.

Figure 6. An illustration of an overnight stop site, the "ranchos", knots in the routes that would later become villages.

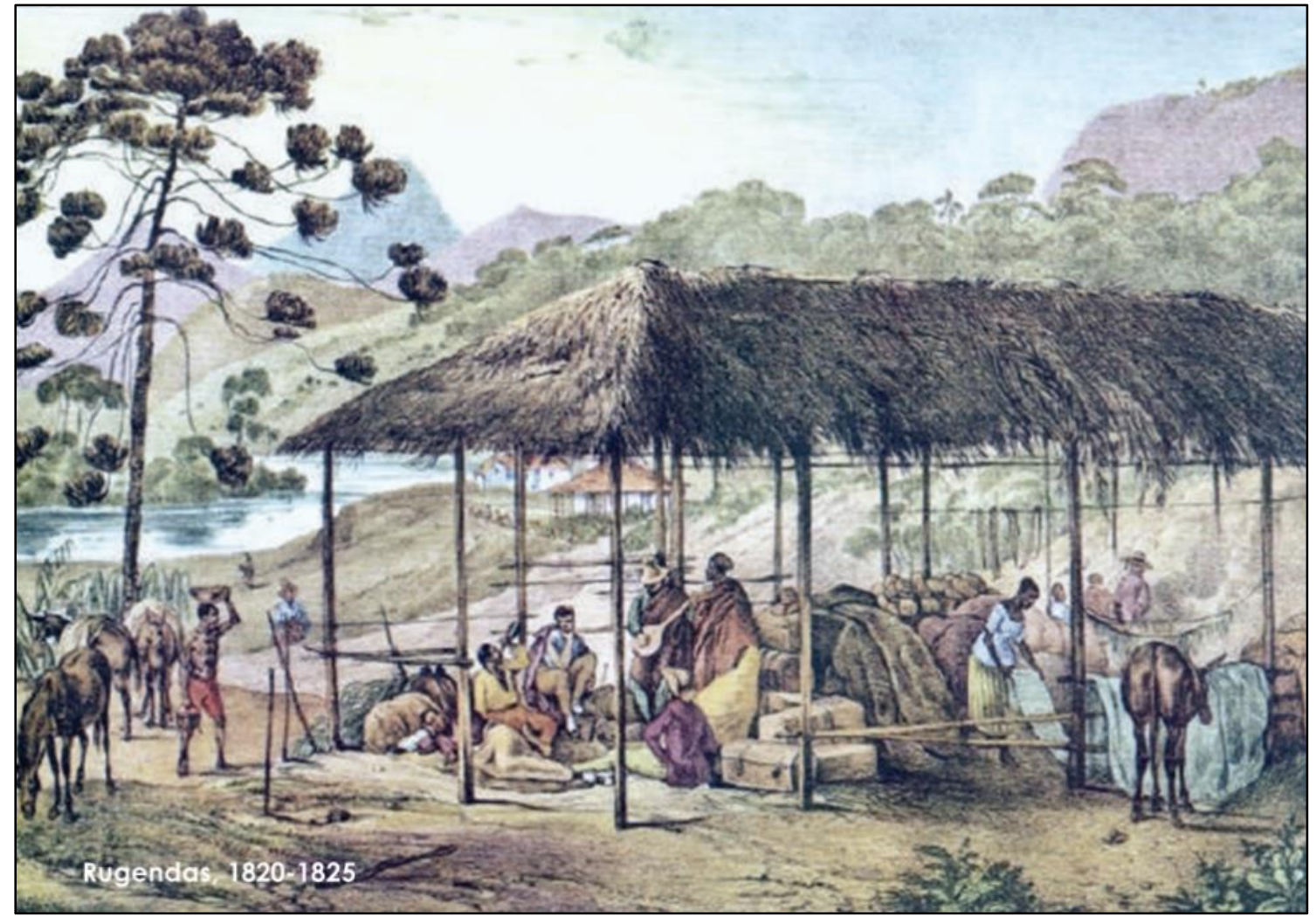

Source: Rugendas, circa 1820-1825.

A landscape agency that, despite being connected to the plantation system needs, acts differently, also promoting its characteristic marks in the landscape. Many trails used by drovers with their mules disappeared overgrown by the woods when they were abandoned, but others resisted and were re-signified and now have various uses, such as the Gold Trail, in Serra da Bocaina, with nearly forty kilometers of stone footpath (Figure 7) made in the XIX century and today used for ecotourism ${ }^{51}$.

${ }^{51}$ Rogério Oliveira. "Fruto da terra e do trabalho humano..." 
Figure 7. - Bicentenary stone footpath section that crosses the Serra do Mar slopes, connecting the Paraíba do Sul Valley to Paraty's ports.

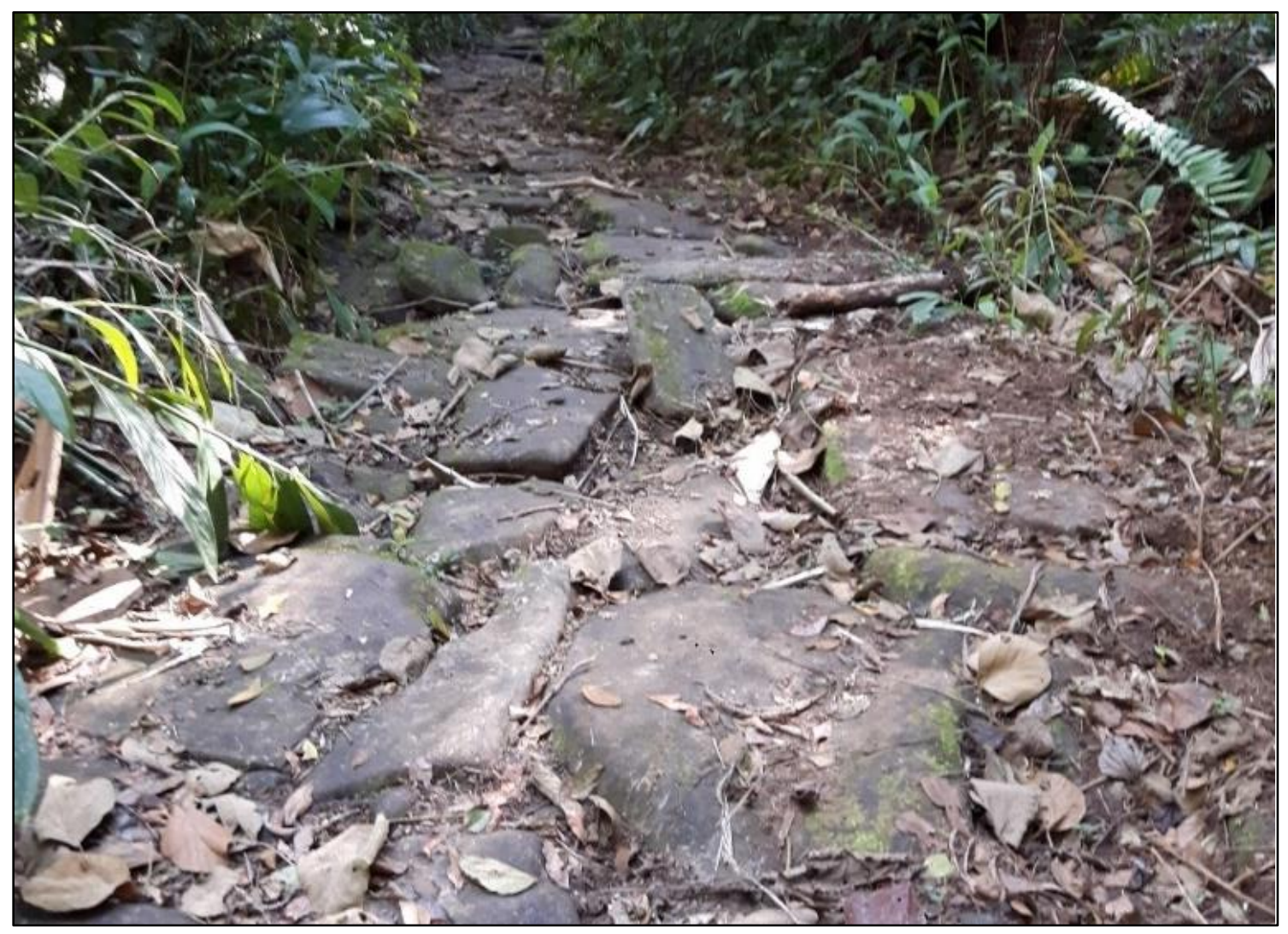

Source: Lucas Brasil, 2018.

\section{AFRICAN AGENCY}

Brazil is the place in the Americas where more enslaved Africans were brought $i^{52}$. Nevertheless, Africans participation in Brazilian landscape production is often seen as subservient agents, who could not contribute to the shaping of Brazilian colonial spaces. On the other hand, the new tropical environment in which they were forced to work referred, in certain aspects, to their homeland, which allowed certain parallels and resistance and resignifications forms. Since they are agents who carry a particular culture, with knowledge inherited from their homeland and which have been merged with the empirical experiences in the New World, their practices should be the focus of new studies, ${ }^{53}$ as the ones that Andrew Sluyter did, revealing the origin

\footnotetext{
52 Rafael dos Anjos. "Matrizes Africanas do Território Brasileiro". In História e Geografia do Vale do Paraíba. Edited by Neusa Fernandes and Olivio G. P. Coelho, (Rio de Janeiro: Instituto Histórico e Geográfico de Vassouras, 2013): 45-58.

53 Judith A. Carney and Robert Voeks. "Landscape legacies of the African diaspora in Brazil." Progress in Human Geography, 27, 2, (2003): 139152
} 
of the horseback lassoing technique, developed by African enslaved in the New World, a herd management practice well disseminated nowadays, ${ }^{54}$ a clear example of black's contribution to the socioecological relations' development in the Americas.

One of these resistance forms can be found in building your diet according to cultural preferences. While the plantation system was guided by the Portuguese agency, Africans developed their forms of landscape management that met their dietary preferences, inscribing their needs in the landscape through food crops whose origins were their homelands. ${ }^{55}$ In that manner, they were responsible for food staples introduction, acclimatization, and dissemination through the Brazilian landscape. The election of certain species, their cultivation, and reproduction in the colonial spaces are actions that reverberate in current landscapes, as they are part of the biocultural heritage, not only of the Paraíba Valley but also of many parts of Brazil. ${ }^{56}$

In this sense, it is extremely interesting the Baron de Paty do Alferes (Francisco Peixoto de Lacerda Werneck) manual - "Memory on the founding of a farm in the province of Rio de Janeiro". Recognizing slavery as one of the cornerstones of a coffee farm, the author reserves several lines in describing how to proceed with enslaved Africans. He also wrote about the importance of having their crops:

The farmer should, as close as possible, set aside a lot of lands where blacks do their farming, plant their coffee, their corn, beans, potatoes, yam, cassava, sugarcane, etc. (...). These fields, and the product that they take from them, make them acquire a certain love for the country, distract them a little from slavery, and entertain with its little right of ownership ${ }^{57}$.

From a spatial point of view, the land granted to the enslaved blacks for planting was not the most fertile or easy to work with, probably occupying marginal portions of the property or at the slave houses' backs. But all the elements represented here are enough to characterize them as farm's internal supply crops,

\footnotetext{
${ }^{54}$ Andrew Sluyter and Chris Duvall. "African Fire Cultures, Cattle Ranching, and Colonial Landscape Transformations in the Neotropics." Geographical Review, 106, 2, (2016): 294-311

${ }^{55}$ Carney and Voeks. "Landscape legacies of the African diáspora..."

56 Judith Carney and Rosa Acevedo. "Plantas de la diáspora africana en la agricultura del Brasil." Revista TransVersos 10, (2017): 09-34.

$57 \mathrm{O}$ fazendeiro deve, o mais próximo que for possível, reservar um bocado de terra onde os pretos façam as suas roças, plantem o seu café, 0 seu milho, feijão, batata, cará, aipim, cana, etc (...). Estas suas roças, e o produto que delas tiram, faz-lhe adquirir certo amor ao país, distraí-los um pouco da escravidão, e entreter com esse seu pequeno direito de propriedade. Werneck. Memoria sobre a fundação e costeio de uma fazenda, p.63-64.
} 
demonstrating how there was a variety of know-hows that converged in a coffee farm so that its operation and its dynamics could be assured.

Werneck's writings also reaffirm the peasant gap existence by allowing us to glimpse a great landlord's point of view on these tracts of land made available to the enslaved. The peasant gap, a concept that attests that there were possibilities for captive Africans to manage their own crops, ${ }^{58}$ reveals the active participation of this socially invisible segment in Brazilian history, and allows us to understand the reasons why this interstice in the slave regime lasted until this system abolition. In fact, what happened was a transfer of the master's responsibility to provide food to slaves: while the former was free of this obligation and its costs of maintaining and reproducing the labor force were minimized, the latter had to set aside their only day of rest to work on their crops, at the risk of having their diet affected if they did not. ${ }^{59,60}$

Like Oliveira and Fraga, ${ }^{61}$ we seek to shed light on other agencies, in the landscape. By interpreting the charcoal production ecological consequences, undertaken in short by former slaves, those authors could remove those forgotten blacks from their social invisibility presenting a narrative that recognizes them as participants not only in Brazil landscape shaping but ultimately in the Brazilian space construction. Those marks in the landscape, although sometimes small or noticed by few, are in fact a material evidence of other agencies in our spaces from the past. The species brought by the blacks for food or medicinal use and the landscape management techniques employed by them are legacies that can still be found not only in the Paraíba do Sul River Valley, but also in many parts of Brazil.

It is important to stress that those were not the only spatial strategies deployed by Africans in colonial Brazil. The quilombos were sites where fled slaves could seek refuge and were managed by blacks, producing their food and securing their existence ${ }^{62}$. Those are just few and generalist words to briefly define quilombos

\footnotetext{
58 Ciro Flamarion "A brecha camponesa ..."

${ }^{59}$ Maria Yedda Linhares and; Francisco Silva. "A questão da agricultura de subsistência"

60 Ciro Flamarion "A brecha camponesa..."

${ }^{61}$ Rogério R de Oliveira; Joana Stingel Fraga. "Metabolismo social de uma floresta e de uma cidade: paisagem, carvoeiros e invisibilidade social no Rio de Janeiro dos séculos XIX e XX". GEOPUC-Revista do Departamento de Geografia da PUC-Rio, 4, 7,(2011): 1-18

62 Rafael dos Anjos. "Matrizes Africanas do Território Brasileiro..."
} 
since its richness and complexity are so enormous that many theses can be written about them. Here, we mention them, but cannot make profound analyzes on them.

Although coffee cultivation was a potent, organized, profit-maximizing, wealth-generating activity, it was not the only activity to be carried out in the Paraíba Valley. Thus, it is noteworthy that coffee farms turned to coffee production, but not only to that. The establishment of vast landlord farms brought with it a wider network of commerce, crafts, villages and small towns to the detriment of the Atlantic Forest, which had to give space to human activities. Thus, it can be generalized that coffee cultivation took place on the slopes in most cases, while massapê lands, as Taunay referred to alluvial lands, typically located in the lower elevation compartments of the relief, were cultivated with sugarcane and food staples (Figure 8), and the pastures occupied less arable land, often infertile to other crops proper development.

Figure 8. - Schematic representation of the most probable landscape segmentation in the XIX century Paraíba do Sul Valley.

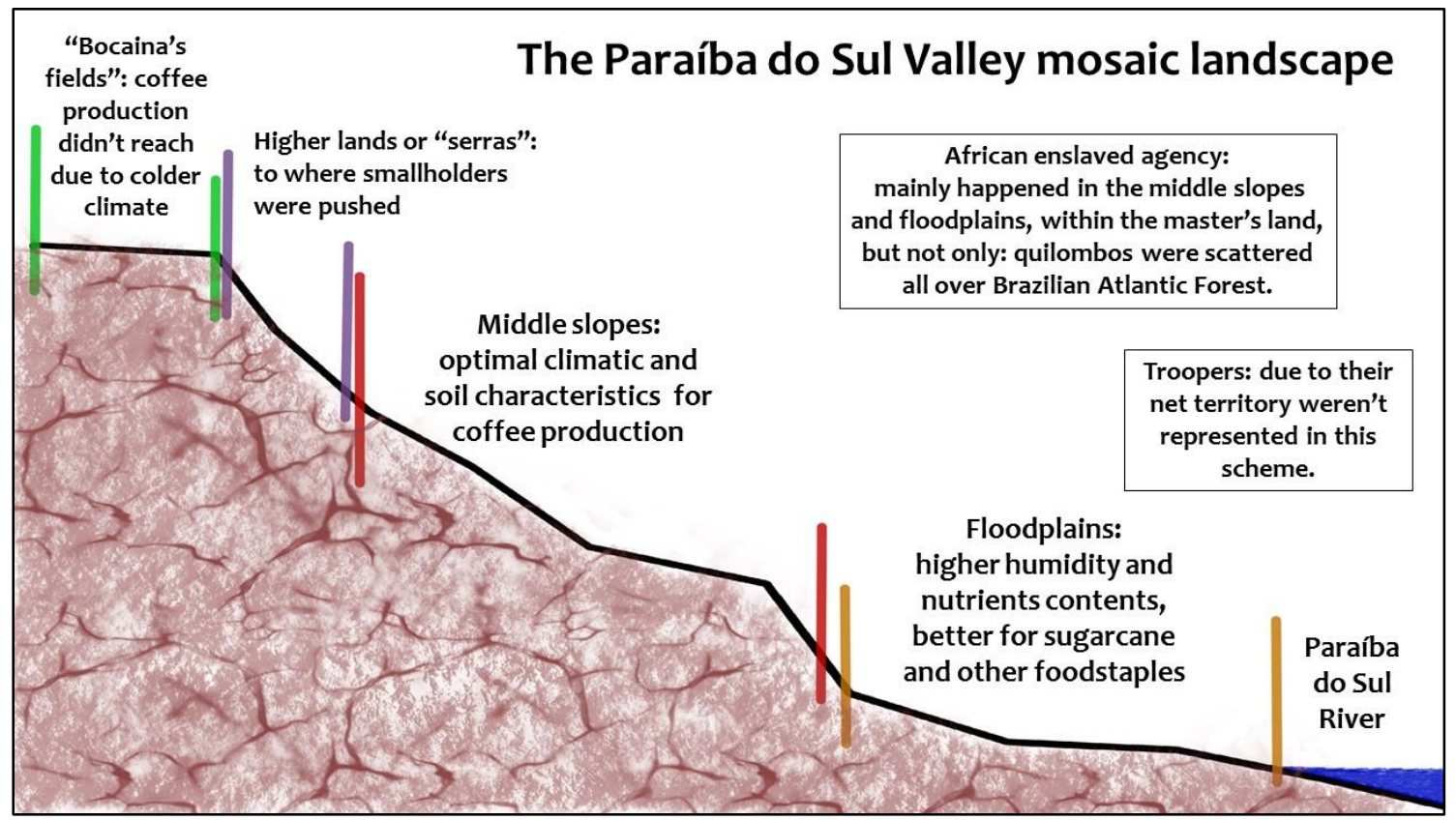

Source: Lucas Brasil, 2020.

The landscape mosaics formed by different material structures of the coffee production cycle were important means of production. At the end of this cycle, many of these elements form structures of the landscape that still exist today. and, in part, they contribute to forming mosaics in the landscape. 


\section{FINAL REMARKS}

This work was also aimed to highlight other farming practices, performed, in general, by defined social groups, homogeneous enough to be possible a generalization exercise in order to add new information to landscape studies of the Paraíba do Sul River Valley. Those groups often have their agency forgotten or diminished in historiography. Even though they occupied marginalized or peripheral sites in the landscape, they changed the nature around them. Spatializing such past activities and social groups in the landscape shows us what was previously hidden, omitted by the traditional historical narrative, generating new layers of information for a theme already worked on by historians, but little exercised among Brazilian historical geographers. The importance for present and future studies of past landscapes is to understand the overlap of different land uses over time, also helping to understand the environmental conditions and resilience shown by socioecological systems today. It is extremely relevant in decision-making in forest restoration actions, ${ }^{63}$ protected areas management and to guide public policies.

In this regard, the Paraíba do Sul River Valley, due to coffee cycle developments (which are some more, others less noticeable in the landscape), is a living laboratory for the promotion of reforestation projects, forest corridors, sustainable agricultural production, spring recovery, cooperative formation, and cultural and ecological tourism.

Offering this spatial point of view to historical processes exudes the mosaic complexity that composed the Paraiba do Sul Valley nineteenth-century landscape and how it can reflect on the present landscape. It allows us to think about irradiation points, as well as areas that were not reached by the coffee expansion process and the reasons for it. It allows the researcher to think about axes, vectors of transformation in space, preferential paths or barriers to the advancement of spatial phenomena, enriching our understanding of the historical process as a whole.

${ }^{63}$ Rogério Oliveira. "Mata Atlântica, paleoterritórios e história ambiental". 


\section{ACKNOWLEDGMENTS}

We would like to thank the Pontificia Universidade Católica - PUC Rio, for providing the doctoral grant for Lucas Brasil that enabled this research, and also to the Conselho Nacional de Desenvolvimento Científico e Tecnológico (CNPq) for a research grant to Rogério Oliveira. Also, we want to thank the Instituto Moreira Salles for providing some of the historical images from their collection to this publishing. We'd like to thank all the Laboratório de Biogeografia e Ecologia Histórica participants who contributed with some ideas for this writing. For last, but not least, we would like to thank the ICEHO for organizing the Third World Congress on Environmental History at Florianopolis, where we had the opportunity to debate with fellow researchers and come with new perspectives and ideas for this work writing.

\section{REFERENCIAS}

Adi E. Lazos-Ruiz, Ana Luíza Coelho Netto, Marcelo Dantas, e Rogério Ribeiro Oliveira. "Cenários do passado no Vale do Rio Paraíba do Sul." In Geografia Histórica do Café no Vale do Rio Paraíba do Sul, edited by Rogério R. Oliveira e Adi E.LazosRuiz, (Rio de Janeiro: Editora PUC-Rio, 2018): p.61-82

Alex Peloggia. "Relíquias da destruição: registros geológicos da supressão da Mata Atlântica no Vale do Paraíba." In Metamorfoses florestais: culturas, ecologias e as transformações históricas da Mata Atlântica edited by Diego Cabral and Ana Bustamante. (Curitiba: Prismas, 2016): p.286-304

Alexandro Solórzano; Rogério R. de Oliveira, Rejan Rodrigues Guedes-Bruni. "Geografia, História e Ecologia: criando pontes para a interpretação da paisagem." Ambiente \& Sociedade, 12, 1, (2009): p.49-66

Alfredo Ellis Junior. "O ciclo do muar". Revista de Historia, 1, 1, (1950): 73-81

Andrew Sluyter and Chris Duvall. "African Fire Cultures, Cattle Ranching, and Colonial Landscape Transformations in the Neotropics." Geographical Review, 106, 2, (2016): p;294-311

Antonio Carlos Diegues. O mito moderno da natureza intocada. (São Paulo: Hucitec, 1996): 169p.

Azziz Nacib Ab'Saber and Nilo Bernardes. "O Vale do Paraíba, Serra da Mantiqueira e arredores de São Paulo". In Congresso Internacional De Geografia. (Rio de Janeiro: CNG, 1958): 303p. 
Carlos Augusto Taunay. Manual do agricultor brasileiro. (São Paulo: Editora Companhia das Letras, 2001): 327p

Ciro Flamarion S. Cardoso. "A brecha camponesa no sistema escravista" [1979]. In.: Camponeses brasileiros: leituras e interpretações clássicas, v. 1. Edited by Clifford Andrew Welch et al. (São Paulo: Editora UNESP, 2009).

Constantino Fraga. Resenha histórica do café no Brasil. Agricultura em São Paulo 10,1, (1963): p.1-21.

Donald Ugent e Linda W. Peterson, "Archeological Remains of Potato and Sweet Potato in Peru," CIP Circular, 16 (1988): p.1-10.

Jeronimo de P. Silva, "Índios do Vale do Paraíba". In História e Geografia do Vale do Paraíba, edited by Neusa Fernandes and Olivio G. P. Coelho, (Rio de Janeiro: Instituto Histórico e Geográfico de Vassouras, 2013): p.81-86.

José Augusto Pádua. Um sopro de destruição: pensamento político e crítica ambiental no Brasil escravista, 1786-1888. (Rio de Janeiro: Zahar, 2002): 318p.

Juan David Delgado Rozo. "Entre la materialidad y la representación: reflexiones sobre el concepto de paisaje en geografía histórica." Cuadernos de Geografía, 19, (2010): p.77-86

Judith A. Carney and Robert Voeks. "Landscape legacies of the African diaspora in Brazil." Progress in Human Geography, 27, 2, (2003): p.139-152

Judith Carney and Rosa Acevedo. "Plantas de la diáspora africana en la agricultura del Brasil." Revista TransVersos 10, (2017): p.09-34.

Jurandyr Luciano Sanches Ross. Ecogeografia do Brasil: subsídios para planejamento ambiental. (São Paulo: Oficina de Textos, 2006): 208p.

Luiz Peixoto de Lacerda Werneck. Memoria sobre a fundação e costeio de uma fazenda na provincia do Rio de Janeiro: Pelo Barão do Paty do Alferes, e annotada pelo Dr. Luiz Peixoto de Lacerda Werneck (1863)

Marcelo E. Dantas, e Ana Luiza Coelho Netto. "Resultantes geo-hidroecológicas do ciclo cafeeiro (1780-1880) no médio vale do rio Paraíba do Sul: uma análise qualiquantitativa." Anuário do Instituto de Geociências, (1996): p. 61-78.

Maria Verónica Secreto. "Dominando la floresta tropical: desbravamentos para el café paulista (Brasil siglo XIX). Theomai, 1, 2000

Maria Yêda Linhares. "Pecuária, alimentos e sistemas agrários no Brasil (séculos XVII e XVIII)". Arquivos do Centro Cultural Calouste Gulbenkian, Le Portugal et l'Europe Atlantique, le Brésil et l'Amérique Latine, 34, (1996)

Maria Yedda Linhares; Francisco Carlos Teixeira Silva. "A questão da agricultura de subsistência" [1981]. In: Camponeses brasileiros: leituras e interpretações clássicas. 
Edited by C. Walch (São Paulo: Editora UNESP, 2009), p. 117-133, p.119.

Matthew Gandy. "Paisagem Estéticas e Ideologia". In.: Paisagens, Textos e Identidade. Edited by Roberto Lobato Corrêa, Zeny Rosendahl. (Rio de Janeiro: EdUERJ, 2004): 179p.

Padre Antonio Caetano da Fonseca. Manual do Agricultor do Generos Alimenticios ou Methodo da cultura mixta destes gêneros nas terras cansadas (Rio de Janeiro: Editores Eduardo \& Henrique Laemmert, 1863)

Paulo César da Costa Gomes. "Quadros Geográficos: uma forma de ver, uma forma de pensar." (Rio de Janeiro: Bertrand, 2017): 160p.

Rafael B. Marquese. "Diáspora africana, escravidão e a paisagem da cafeicultura no Vale do Paraíba oitocentista." Almanack braziliense 7 (2008): p.138-152.

Rafael dos Anjos. "Matrizes Africanas do Território Brasileiro". In História e Geografia do Vale do Paraíba. Edited by Neusa Fernandes and Olivio G. P. Coelho, (Rio de Janeiro: Instituto Histórico e Geográfico de Vassouras, 2013): p. 45-58.

Rogério R. de Oliveira. "'Fruto da terra e do trabalho humano': paleoterritórios e diversidade da Mata Atlântica no Sudeste brasileiro." Revista de História Regional, 20,2, (2015): p. 277-299

Rogério R. de Oliveira. "Mata Atlântica, paleoterritórios e história ambiental". Ambiente E Sociedade 10, 2, (2007): p. 11-23.

Rogério R. de Oliveira; Carlos Engemann. "História da paisagem e paisagens sem história: a presença humana na Floresta Atlântica do Sudeste Brasileiro." EsboçosRevista do Programa de Pós-Graduação em História da UFSC, 18, 25, (2011): p.9-31

Rogério R. de Oliveira; Joana Stingel Fraga. "Metabolismo social de uma floresta e de uma cidade: paisagem, carvoeiros e invisibilidade social no Rio de Janeiro dos séculos XIX e XX". GEOPUC-Revista do Departamento de Geografia da PUC-Rio, 4, 7, (2011): p.1-18

Rogério R. de Oliveira; Verena Winiwarter. "Toiling in Paradise: knowledge acquisition in the context of colonial agriculture in Brazil's Atlantic Forest Context of Colonial Agriculture". Environment and History, 16, (2010): p.483-508

Rogério Ribeiro Jorge. "Quem decide por nós é o IBAMA: As contradições na convivência com as populações locais no Parque Nacional da Serra da Bocaina." In: Olhares geográficos: meio ambiente e saúde. Edited By Helena Ribeiro (São Paulo: Editora Senac, 2005): p.31-64

Ruy Moreira. A formação espacial brasileira: contribuição crítica aos fundamentos espaciais da geografia do Brasil (Consequencia: Rio de Janeiro, 2014): 320p.

Sérgio Buarque de Holanda. Caminhos e Fronteiras. (São Paulo: Companhia das Letras, 2017): 354p. 
Affonso d'Escragnolle Taunay. Pequena História do Café no Brasil 1727-1937. (Rio de Janeiro: Departamento Nacional do Café, 1945): 558p

Stanley J Stein. Vassouras um município brasileiro do café, 1850-1900. (Rio de Janeiro: Nova Fronteira, 1990): 361p.

Warren Dean. A ferro e fogo: a história e a devastação da mata atlântica Brasileira (São Paulo: Companhia das Letras, 1997): 484p. 


\title{
Acerca de manuales agrícolas, jardines y cafetales: mosaicos y transformación del paisaje en el valle de Paraiba do Sul, Brasil
}

\begin{abstract}
RESUMEN
Los ciclos económicos a menudo se han convertido en la matriz del paisaje, en un proceso híbrido de transformación sociedad-naturaleza, dejando legados distintos en él. La plantación de café mostró una gran productividad en el valle de Paraíba do Sul en detrimento de los bosques, lo que resultó en cambios profundos en los ciclos geohidricos. Aunque la transformación por el café ha sido significativa a escala espacial y en los cambios ambientales, el paisaje del valle de Paraíba debe entenderse desde una perspectiva más amplia. También había otras culturas en el paisaje dentro de los límites de grandes propiedades o fuera de ellas. Este trabajo tiene como objetivo reconocer la organización espacial de estas culturas y desarrollar una comprensión del patrón del paisaje cafetero, mostrando el desempeño de diferentes actores sociales. La metodología consistió en una revisión bibliográfica y análisis de manuales agrícolas históricos. Esta investigación mostró que el conocimiento colonial desarrolló una compartimentación del paisaje, espacializando los cultivos de acuerdo con la evidencia pedológica y topográfica.
\end{abstract}

Palabras Clave: café; Manuales agrícolas; Bosque Atlántico, legados socioecológicos, conocimiento colonial. 